\title{
ANALYSIS OF BUSINESS STRATEGY WITH CANVAS MODEL BUSINESS (BMC) APPROACH
}

\author{
Rr. Erlina ${ }^{1}$, Toto Gunarto ${ }^{2}$, Faila Shofa ${ }^{3}$ \\ \{erlina.feb62@gmail.com¹ ${ }^{1}$ toto.gunarto@yahoo.co.id ${ }^{2}$, faila.shofa@feb.unila.ac.id ${ }^{3}$ \} \\ Faculty of Economics and Business, University of Lampung, Indonesia
}

\begin{abstract}
The increasing competition in the bakery business has made Holland Bakery to be able to maintain its achievements with a business strategy. So, a business model is needed as a form of strategy that can be carried out by analysts using the Business Model Canvas, where each building block is also analyzed by the IFE \& EFE Matrix, IE Matrix, SWOT Matrix and Blue Ocean Strategy combined with the Business Model Canvas. The results of the IFE matrix analysis resulted in a total score of 2.76, and EFE produced a score of 2.59. The results of the IE Holland Bakery Lampung matrix analysis are in quadrant V, indicating that Holland Bakery Company is currently in a strategic position to maintain (Hold and Maintain).
\end{abstract}

Keywords: Business Strategy, Business Model Canvas, IFE Matrix, EFE Matrix, IE Matrix, SWOT Matrix, Blue Ocean Strategy, Holland Bakery Lampung.

\section{Introduction}

\section{Research Background}

The bakery business in the city of Bandar Lampung is growing due to the increasing consumption of bread in the community. Bread is not only a staple food substitute for rice but also practical to serve and contains nutrients and protein. New companies with modern services are taking advantage of this business opportunity so that they can compete with previous bakeries. Holland Bakery is a fairly senior bakery in Bandar Lampung that strives to continue to develop its products and create the latest innovations while maintaining its own characteristics. Bread products from other companies have a wide variety of products, the same quality, services that are not much different and provide attractive promotions, are one of the things that make consumers switch to these bakery products. Holland Bakery has produced various high-flavored breads with various content variants, cleanliness and quality of taste have always been a priority in production, Holland Bakery's Halal certificate is also an advantage in competing with other bakery products, but in terms of prices offered by products Holland Bakery including companies that provide quite expensive prices. The price offered by Holland Bakery is more expensive than its competitors. Holland Bakery tries to continue to dominate the brand which shows the strong influence of the brand Holland Bakery on consumer satisfaction and loyalty in Bandar Lampung. The following is a picture of competitive market share Holland Bakery's in Bandar Lampung.

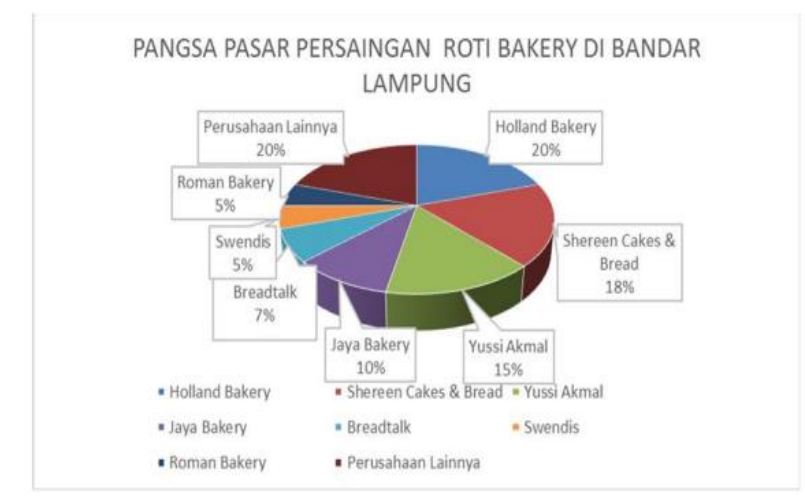


The picture above shows that the bread business in Bandar Lampung has a fairly tight level of competition. Holland Bakery in the market position in Bandar Lampung is at the top of the market followed by Shereen Cake \& Bread, and Yussi Akmal. In addition to bakery types, Holland Bakery also has substitute competitors such as J.CO, Dunkin Donut and others.

\section{The formulation of the problem}

Holland Bakery Requires a strategy in facing competition in the bread business in Bandar Lampung. The business model canvas (BMC) is used as a tool to help Holland Bakery see how the business model will be. According to Osterwalder the business model canvas is a business model that is able to simply describe how an organization provides and captures the value of business activities carried out to make money [1]. Through BMC Holland Bakery, you will see an outline of the business, but every element related to the business will appear complete and detailed. Evaluation of each element will facilitate analysis of what is not right, and in the end the company can take steps to be able to maintain business performance. Based on this, the problem formulations in this study are:

How is the strategy to maintain a suitable business at Holland Bakery in Bandar Lampung with approach business model canvas?

\section{Research Objectives}

The purpose of this study is to determine the design of a new business model as a form of business defense strategy for Holland Bakery Bandar Lampung with approach business model canvas.

\section{LITERATURE REVIEW}

\section{Business Model Canvas}

According to Osterwalder and Pigneur [1] Business Model Canvas (BMC) is one of the strategic tools used to describe a business model and describe the rationale for how organizations create, deliver, and capture value. The canvas business model is depicted through nine basic building blocks that show the logic of how the company intends to make money. These nine blocks cover the four main business areas namely customer, offering, infrastructure and financial feasibility.

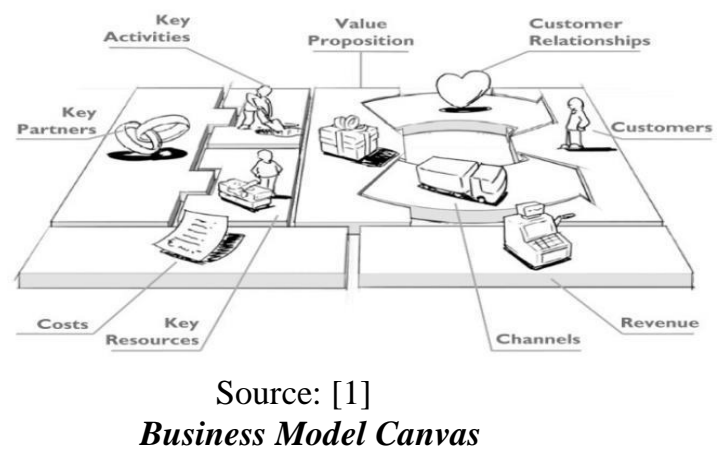

\section{SWOT Analysis}

According to Rangkuti the tool used to compile the company's strategic factors is the SWOT matrix [2]. This matrix can clearly describe how the external opportunities and threats faced by a company can be adjusted according to its strengths and weaknesses. This matrix can produce four sets of possible strategic alternatives [2]. The four possible alternative strategies that can be formulated are as follows: 


\begin{tabular}{|c|c|c|}
\hline EFAS & $\begin{array}{l}\text { STRENGTHS (S) } \\
\text { Tentukan 5-10 faktor- } \\
\text { faktor kekuatan internal }\end{array}$ & $\begin{array}{l}\text { WEAKNESSES }(W) \\
\text { Tentukan 5-10 faktor- } \\
\text { faktor kelemahan } \\
\text { internal }\end{array}$ \\
\hline $\begin{array}{l}\text { OPPORTUNITIES (O) } \\
\text { Tentukan 5-10 faktor } \\
\text { peluang eksternal. }\end{array}$ & $\begin{array}{l}\quad \text { STRATEGI SO } \\
\text { Ciptakan strategi yang } \\
\text { menggunakan kekuatan } \\
\text { untuk memanfaatkan } \\
\text { peluang }\end{array}$ & \begin{tabular}{|l}
\multicolumn{1}{|c}{ STRATEGI WO } \\
Ciptakan strategi yang \\
meminimalkan \\
kelemahan untuk \\
memanfaatkan peluang \\
\end{tabular} \\
\hline $\begin{array}{l}\quad \text { TREATHS (T) } \\
\text { Tentukan 5-10 faktor } \\
\text { ancaman eksternal }\end{array}$ & $\begin{array}{l}\quad \text { STRATEGI ST } \\
\text { Ciptakan strategi yang } \\
\text { menggunakan kekuatan } \\
\text { untuk mengatasi ancaman }\end{array}$ & $\begin{array}{l}\text { STRATEGI WT } \\
\text { Ciptakan strategi yang } \\
\text { meminimalkan } \\
\text { kelemahan dan } \\
\text { menghindari ancaman }\end{array}$ \\
\hline
\end{tabular}

Source: [2]

\section{SWOT Matrix Diagram}

According to [3], a strength, weakness, opportunity and threat matrix is an important matching tool that helps managers develop four types of strategies: SO Strategy (strength-opportunity), WO Strategy (weakness-opportunity), ST Strategy (strength-threat), and WT Strategy (weakness-threat).

\section{Blue Ocean Strategy}

Blue Ocean Strategy (BOS) is a business strategy that creates new market spaces and does not have competitors [4]. In starting the blue ocean strategy, there are several steps that must be taken. Kim and Mouborgne [4] say the value innovation process is the key to the successful implementation of BOS. This value innovation can be achieved by building a framework for four strategic steps that must be implemented (the four-action framework) which deals with four questions, namely:

1. Eliminate Key: What factors should be eliminated from factors that have been taken for granted by the industry?

2. Reduce $\quad$ : What factors can be reduced to below industry standards?

3. Raise : What factors can be raised above the industry standard?

4. Create : What factors have not been the focus of the industry's offering until it needs to be created?

\section{Research Method}

The type of research used is descriptive research, data collection is done by collection techniques with triangulation (combination) of sources, data analysis is inductive / qualitative, and the results of qualitative research emphasize meaning rather than generalization. Analytical tools used in formulating internal factors, strengths and weaknesses, and external opportunities and threats. The next step is to determine the IFE matrix, EFE matrix, IE matrix, SWOT matrix, and Blue Ocean Strategy to determine the Business Model Canvas in the company.

\section{Results and Discussion}

Matrix Analysis of IFE (Internal Factor Evaluation)

\begin{tabular}{|l|c|c|c|}
\hline Internal Strategy Factor & Weight & $\begin{array}{c}\text { Rat } \\
\text { ing }\end{array}$ & $\begin{array}{c}\text { Value } \\
\text { Score }\end{array}$ \\
\hline Strength (strength) & $\mathbf{0 . 0 3 5 5}$ & 4 & 0.1422 \\
\hline $\begin{array}{l}\text { Holland Bakery brand that is } \\
\text { well known }\end{array}$ & $\mathbf{0 . 0 3 5 5}$ & 4 & 0.1422 \\
\hline High customer loyalty & $\mathbf{0 . 0 3 5 5}$ & 4 & 0.1422 \\
\hline $\begin{array}{l}\text { good quality products taste, } \\
\text { texture and aroma }\end{array}$ & $\mathbf{0 . 0 3 5 5}$ & 4 & 0.1422 \\
\hline has variations diverse products & $\mathbf{0 . 0 3 5 5}$ & 4 & 0.1422 \\
\hline $\begin{array}{l}\text { Able to sell through an online } \\
\text { network system }\end{array}$ & $\mathbf{0 . 0 3 5 5}$ & 4 & $\begin{array}{c}0.1422 \\
\text { The }\end{array}$ \\
\hline $\begin{array}{l}\text { Have professional employees } \\
\text { logo reflects a modern bakery }\end{array}$ & $\mathbf{0 . 0 3 5 5}$ & 4 & 0.1422 \\
\hline has a Halal certificate & $\mathbf{0 . 0 3 5 5}$ & 4 & 0.1422 \\
\hline $\begin{array}{l}\text { Has a clean and comfortable } \\
\text { place }\end{array}$ & $\mathbf{0 . 0 3 5 5}$ & 4 & 0.1422 \\
\hline $\begin{array}{l}\text { has a website and all social } \\
\text { media }\end{array}$ & $\mathbf{0 . 0 3 5 5}$ & 4 & 0.1422 \\
\hline $\begin{array}{l}\text { Clean and hygienic equipment } \\
\text { and skilled chefs }\end{array}$ & $\mathbf{0 . 0 3 5 5}$ & 4 & 0.1422 \\
\hline $\begin{array}{l}\text { Many branches spread across } \\
\text { Bandar Lampung }\end{array}$ & $\mathbf{0 . 0 3 5 5}$ & 4 & 0.1422 \\
\hline
\end{tabular}

\begin{tabular}{|l|c|c|c|}
\hline $\begin{array}{l}\text { Delivery services via online } \\
\text { motorcycle taxis. }\end{array}$ & $\mathbf{0 . 0 3 5 5}$ & 4 & 0.1422 \\
\hline strategic store location & $\mathbf{0 . 0 3 5 5}$ & 4 & 0.1422 \\
\hline holds Disney character license & $\mathbf{0 . 0 3 5 5}$ & 4 & 0.1422 \\
\hline Sub total & 1 & & $\mathbf{2 . 1 3 4 3}$ \\
\hline Weakness (Weakness) & \multicolumn{3}{|l|}{} \\
\hline $\begin{array}{l}\text { average middle to upper class } \\
\text { customers }\end{array}$ & $\mathbf{0 . 0 5 9 4}$ & 1.2 & 0.0713 \\
\hline Bread does not last long & $\mathbf{0 . 0 6 1 0}$ & 1 & 0.0610 \\
\hline $\begin{array}{l}\text { There is no unity in the product } \\
\text { packaging }\end{array}$ & $\mathbf{0 . 0 5 9 4}$ & 1.2 & 0.0713 \\
\hline $\begin{array}{l}\text { organizational structure is too } \\
\text { broad }\end{array}$ & $\mathbf{0 . 0 5 6 3}$ & 1.6 & 0.0901 \\
\hline $\begin{array}{l}\text { the management is quite } \\
\text { complicated }\end{array}$ & $\mathbf{0 . 0 5 6 3}$ & 1.6 & 0.0901 \\
\hline $\begin{array}{l}\text { majority of raw materials are } \\
\text { not available in country }\end{array}$ & $\mathbf{0 . 0 5 7 9}$ & 1.4 & 0.0810 \\
\hline $\begin{array}{l}\text { Promotion and advertising is not } \\
\text { yet complete to communities }\end{array}$ & $\mathbf{0 . 0 5 7 9}$ & 1.4 & 0.0810 \\
\hline $\begin{array}{l}\text { price of products tend to be } \\
\text { expensive }\end{array}$ & $\mathbf{0 . 0 5 7 9}$ & 1.4 & 0.0810 \\
\hline Sub total & 1 & & $\mathbf{0 . 6 2 7 2}$ \\
\hline Total & & & $\mathbf{2 . 7 6 1 6}$ \\
\hline
\end{tabular}


EFE Matrix Analysis (External Factor Evaluation)

\begin{tabular}{|l|c|c|c|}
\hline External Strategy Factor & $\begin{array}{c}\text { Weigh } \\
\mathbf{t}\end{array}$ & Rating & $\begin{array}{c}\text { Value } \\
\text { Score }\end{array}$ \\
\hline Opportunities (opportunities) & \multicolumn{4}{|l|}{} \\
\hline Lampung as a tourism city & $\mathbf{0 . 0 4 4 9}$ & 4 & 0.1797 \\
\hline $\begin{array}{l}\text { Consumptive culture of the } \\
\text { people of Bandar Lampung }\end{array}$ & $\mathbf{0 . 0 4 4 9}$ & 4 & 0.1797 \\
\hline $\begin{array}{l}\text { population growth in Bandar } \\
\text { Lampung }\end{array}$ & $\mathbf{0 . 0 4 4 9}$ & 4 & 0.1797 \\
\hline $\begin{array}{l}\text { consumer knowledge of Holland } \\
\text { Bakery products }\end{array}$ & $\mathbf{0 . 0 4 8 6}$ & 3.8 & 0.1849 \\
\hline outlet increase annually & $\mathbf{0 . 0 5 9 8}$ & 3.2 & 0.1916 \\
\hline $\begin{array}{l}\text { changing consumption pattems } \\
\text { Rice replaced the consumption of } \\
\text { bread }\end{array}$ & $\mathbf{0 . 0 4 5 3}$ & 4 & \\
\hline Business activities are expanding & $\mathbf{0 . 0 4 9 0}$ & 3.8 & 0.1864 \\
\hline
\end{tabular}

\begin{tabular}{|l|c|c|c|}
\hline $\begin{array}{l}\text { Bread started to become daily } \\
\text { necessities }\end{array}$ & $\mathbf{0 . 0 4 9 0}$ & 3.8 & 0.1864 \\
\hline social media is growing & $\mathbf{0 . 0 4 5 3}$ & 4 & 0.1813 \\
\hline Sub-total & \multicolumn{3}{|l|}{} \\
\hline Threats (threats) & \multicolumn{3}{|l|}{} \\
\hline consumer move to another bakery & $\mathbf{0 . 0 8 1 5}$ & 1.6 & 0.1304 \\
\hline $\begin{array}{l}\text { competitors start copying product } \\
\text { innovations }\end{array}$ & $\mathbf{0 . 0 8 1 5}$ & 1.6 & 0.1304 \\
\hline Fluctuating consumer tastes & $\mathbf{0 . 0 7 9 0}$ & 1.8 & 0.1422 \\
\hline competitors have lower prices & $\mathbf{0 . 0 7 9 0}$ & 1.8 & 0.1422 \\
\hline $\begin{array}{l}\text { supplier or raw material } \\
\text { constraints }\end{array}$ & $\mathbf{0 . 0 8 4 8}$ & 1.4 & \\
\hline Market prices that often fluctuate & $\mathbf{0 . 0 8 2 3}$ & 1.6 & 0.1318 \\
\hline tastes and flavors diverse society & $\mathbf{0 . 0 7 9 4}$ & 1.8 & 0.1429 \\
\hline Sub total & & & $\mathbf{0 . 9 3 9 0}$ \\
\hline Total & 1 & & $\mathbf{2 . 5 9 0 5}$ \\
\hline
\end{tabular}

\section{IE matrix analysis Holland Bakery}

IFE matrix analysis results yielded a total score of 2.76 for the total score shows that the company's ability to use force to overcome the weaknesses are in the medium level. The results of the EFE matrix analysis resulted in a score of 2.59. The total score indicates that the company can take advantage of opportunities and overcome threats at an average level. The results of the two total scores are then described in the IE (Internal-External) matrix to determine the company's current position.

The result of IE matrix analysis in the Figure above shows that Holland Bakery Lampung is in quadrant V. This shows that Holland Bakery Company is currently in a strategic position to maintain and maintain (Hold and Maintain). Based on the company's position, the appropriate alternative strategies used in this quadrant are market penetration and product development strategies which are the two most commonly used strategies for these types of divisions. The market penetration strategy that Holland Bakery can do is by increasing marketing through media online or paper. Product development strategy in the form of adding market segments and increasing the variety of Holland Bakery products.

\section{SWOT Matrix Analysis}

This matrix can produce four alternative strategies, namely the SO (Strengths-Opportunities) strategy, the ST (Strengths-Threats) strategy, the WO (Weakness-Opportunities) strategy, and the WT (strategy Weakness-Threats) which can be formulated through opportunities. key external, key external threats, key internal strengths, and key internal weaknesses as follows:

1. SO Strategy (Strengths-Opportunities)

SO strategy is a strategy that uses the company's internal strengths to take advantage of external opportunities. The following is the SO strategy that has been analyzed by researchers

a. Maintain customer loyalty and improve product quality, attract new customers and retain old customers.

b. Opening cooperation with business partners (banks, suppliers, government and shop partners) in order to increase and develop branches in Bandar Lampung.

2. WO Strategy (Weakness-Opportunities)

WO strategy aims to improve internal weaknesses by taking advantage of external opportunities.

a. Maximizing the use of information media, internet and social media in creating good relationships with customers.

b. Creating Member Cards

3. ST (Strengths-Threats)

Strategy ST strategy uses company strength to avoid or reduce the influence of external threats.

a. Providing rewards to the best employees, to maintain employee loyalty in order to create an increase in service quality and the threat of consumers moving to another bakery.

4. WT strategy (weakness-threats) 
The WT strategy is a defensive tactic aimed at reducing internal weaknesses by avoiding external threats by increasing support facilities (waiting rooms, air conditioning, computerized payments, etc.) and human resources to attract new customers.

\section{Implementation of Blue Ocean Strategy on the Canvas Business Model Holland Bakery}

Based on the Blue Ocean Framework, it can be concluded that there are elements in 9 Building Blocks that are recommended to undergo changes.

1. Raise

The block with increased capabilities is the block Key Resource, which is a Vehicle element that is useful as an additional facility for the distribution process to stores to make it faster, factory and shop facilities need to be upgraded again such as shop facilities that use air conditioning in every store, equipped with seats to wait for services so that consumers feel comfortable in the store. Human resources also need to be improved again in order to create satisfying services for consumers.

\section{Reduce}

The blocks with reduced capability are block cost structures. The most difficult to control cost is the electricity cost. To minimize these costs, Holland bakery must save energy. One way to save energy by turning off unused electrical equipment. You can also replace the equipment with more cost-effective equipment, for example replacing ordinary air conditioners with energy-efficient ones (low watts). Companies can also look for cheaper raw materials, of course, with the many suppliers they have.

\section{Create action}

This is the most widely applied analysis Blue Ocean of BMC companies, namely the first is social media and the official website on the block channel, which is useful as a tool for promotion as well as direct contact with customers. The company element in a key partnership is a form of cooperation carried out by the company to increase the number of sales. Collaboration with banks can help consumers in the transaction process, collaboration with providers can help companies promote their products via SMS sent through providers that are invited to cooperate and the last is collaboration with mini markets or supermarkets to reach a wider range of consumers.

The customer relationship block in this block, the addition of a member card can help Holland Bakery maintain good relations with consumers and can serve as a promotional media besides that the company can increase other income through the creation of a member card. Adding elements to the block, value proportions namely elements or services delivery order can help and make it easier for consumers to buy products offered by Holland Bakery. The Block key resource also needs to experience additional elements in its human resources, namely the addition of employees in the IT department so that they can manage social media and official websites in order to increase promotion in cyberspace. The addition of IT employees will have an impact on promotional activities online on the block key activities.

\section{Eliminate}

The only element omitted is leasing the building on block cost structures. Building investment by owning the building itself will be a long-term investment for the company because the company does not need to rent rental fees again every month. In addition, the value of the building will always increase every year so that it can be a promising investment for the company.

\section{Conclusions}

From the results of the research results, the conclusion that can be drawn is the results of the IE matrix analysis showing that Holland Bakery Lampung is in quadrant V. This indicates that Holland Bakery Company is currently in a strategic position to hold and maintain. From the SWOT Matrix, four alternative strategies are produced, namely the SO (Strengths-Opportunities) strategy, the ST (Strengths-Threats) strategy, the WO (Weakness-Opportunities) strategy, and the WT strategy (Weakness-Threats strategy) which can be formulated through opportunities.

In addition, from the Blue Ocean Strategy on the Canvas Holland Bakery Business Model it can be concluded that there are several things that are recommended to make changes, namely; (1). Raise, which is to increase shop facilities and human resources in order to create satisfying services for consumers. (2). Reduce, namely reducing the cost structure in this case is the cost of electricity. To minimize these costs, Holland bakery must save energy. One way to save energy is to turn off unused 
electrical equipment or replace the equipment with more cost-effective equipment. (3). Create action, adding a member card can help Holland Bakery maintain good relations with consumers and can serve as a promotional media besides that the company can increase other income through the creation of membership cards. And the last one is Eliminate, namely by not renting a building and investing in buildings by owning the building itself will be a long-term investment for the company because the company no longer needs to pay rent every month.

\section{Acknowledgement}

The author's thanks go to the Faculty of Economics and Business, University of Lampung in terms of funding.

\section{References}

[1] A. Osterwalder and Y. Pigneur, "Business Model Generation - Canvas," Wiley, 2010. .

[2] F. Rangkuti, SWOT-Balanced Scorecard. PT. Gramedia Pustaka Utama. Jakarta., 2011.

[3] F. R. David, Strategic Management: Concepts and Cases (Thirteenth Edition). 2011.

[4] W. C. Kim and R. A. Mauborgne, Blue Ocean Strategy, Expanded Edition: How to Create Uncontested Market Space and Make the Competition Irrelevant. 2015. 